\title{
An investigation into food provision and consumption in an orthopaedic rehabilitation hospital in Scotland, UK
}

\author{
L. Williams, J. Jones, H. I. M. Davidson and E. Bannerman \\ Queen Margaret University, Queen Margaret University Drive, Musselburgh, East Lothian, EH21 6UU, UK
}

BAPEN report the 'risk of' malnutrition in individuals admitted to hospitals to be $28 \%$, with this rising to $40 \%$ in medicine for the elderly $^{(1)}$. Food and fluid provision have a central role to play in the management of malnutrition within institutions. Nutrient and foodbased guidance for food provision in hospitals in Scotland ${ }^{(2)}$ has been published to assist health boards meet NHS QIS clinical standards for nutritional care ${ }^{(3)}$. The aim of this study was to evaluate food provision and consumption in an elderly orthopaedic rehabilitation setting to determine the role different eating occasions play in energy and nutrient intakes in this setting.

Weighed plate-wastage method was used to assess food provision and consumption for patients in three orthopaedic rehabilitation wards in a hospital in Scotland. A plated-food service system was in operation and three main meals and three snacks were provided daily with midday and evening meals consisting of two courses each. All foods provided over a $24 \mathrm{hr}$ period were weighed prior to being served and any left-over items were weighed after the patient had finished eating. Snack consumption was observed and recorded. Total food intakes were used to estimate energy and nutrient intakes using WinDiets dietary analysis software and these were compared against standards for food provision in hospitals in Scotland ${ }^{(2)}$ using one-sample t-test. Consumption figures were also determined for each eating occasion as a proportion of food provided.

Food provision and consumption were assessed for 58 patients ( $>65$ years; $12 \mathrm{~m}$ : 46f). Results show all patients were provided with adequate protein to meet the standards for nutrient provision ${ }^{(2)}$. For energy, males were provided with adequate energy $($ mean $=2260 \pm 164 \mathrm{kcal}, \mathrm{NS})$ but this was not the case for females $($ mean $=1630 \pm 60 \mathrm{kcal} p<0.001)$.

\begin{tabular}{|c|c|c|c|c|c|c|c|}
\hline \multirow[b]{2}{*}{ Meal } & \multicolumn{4}{|c|}{ Provision } & \multicolumn{3}{|c|}{ Consumption } \\
\hline & $\begin{array}{l}\text { Mean (SEM) } \\
\text { Energy (kcal) }\end{array}$ & $\begin{array}{c}\text { Mean }(\text { SEM) } \\
\text { Protein }(\mathrm{g})\end{array}$ & $\begin{array}{l}\% \text { Contribution } \\
\text { to total energy } \\
\text { provision }\end{array}$ & $\begin{array}{l}\text { Mean (SEM) } \\
\text { Energy (kcal) }\end{array}$ & $\begin{array}{c}\text { Mean (SEM) } \\
\text { Protein }(\mathrm{g})\end{array}$ & $\begin{array}{l}\% \text { Contribution } \\
\text { to total energy } \\
\text { consumption }\end{array}$ & $\begin{array}{c}\% \text { Of energy } \\
\text { provision }\end{array}$ \\
\hline Breakfast & 397 (15) & $9(0.4)$ & 22.6 & $316(18)$ & $8(0.5)$ & 23.4 & 79.6 \\
\hline Midday & $510(25)$ & $23(1.1)$ & 29 & 380 (26) & 17 (1.1) & 28.2 & 74.5 \\
\hline Evening & $511(20)$ & $28(1.3)$ & 29 & $350(17)$ & $20(1.2)$ & 25.9 & 68.5 \\
\hline Snacks & $342(30)$ & $8(0.9)$ & 19.4 & $310(26)$ & $7(0.8)$ & 23 & 90.6 \\
\hline Totals & $1760(67)$ & 68 (2.6) & & 1349 (63) & $51(2.4)$ & & \\
\hline
\end{tabular}

Despite adequate provision in some cases, not all food provided is consumed, thus there is the potential that individual patients' nutrient requirements are not being met. More than $90 \%$ of snacks provided are consumed and these food items are providing almost one quarter of total energy intakes which is a comparable to the contribution from breakfast and lunch. However snacks only provide $14 \%$ of total protein intakes in contrast to $33 \%$ from the midday meal and $39 \%$ from the evening meal. These results are consistent with previous results found in a care home setting ${ }^{(4)}$.

Reconsideration of conventional food provision (i.e. three main meals with three small snacks) to more frequent, smaller 'meals' with adequate protein content may help maximise food and nutrient intakes, reduce plate-wastage costs and may also reduce deterioration in nutritional status.

1. Russell CA \& Elia M (2009) Nutrition Screening Survey in the UK in 2008. Hospitals, care homes and mental health units. BAPEN.

2. Scottish Government (2008) Food in hospitals: catering and nutrition specification for food and fluid provision and nutritional care in hospitals in Scotland.

3. NHS QIS (2003) Clinical Standards for food, fluid and nutritional care.

4. Cunneen S, Jones, Jacklyn, Davidson, HIM \& Bannerman, Elaine (2011) An investigation of food provision and consumption in a care home setting. BJ Comm Nurs 16 (5), 22-28. 